\title{
Management of mucous membrane pemphigoid with dapsone plus weekly steroid injections in a young patient: a case report
}

\author{
Tratamento de penfigóide membranoso mucoso com dapsona \\ e injeções semanais de esteróide em um paciente jovem: \\ relato de caso
}

\begin{abstract}
Purpose: Mucous Membrane Pemphigoid (MMP) is an autoimmune subepithelial blistering disorder usually affecting older individuals. This paper describes the pharmacological management of MMP in a young patient.

Case description: A 23 year-old woman showed erythematous ulcerative gingiva in the maxillary palatal region and around the retromolar region. A perilesional excisional biopsy was done, and the histologic and immunohistochemical analysis confirmed the clinical diagnosis of MMP as the cause of desquamative gingivitis in this patient. The patient was treated with topical steroids plus daily Dapsone $100 \mathrm{mg}$ and weekly steroid injections $(40 \mathrm{mg})$. The lesions began to resolve after 12 weeks of therapy.

Conclusion: This case of MMP in a young female patient was effectively managed with a combination therapy of topical steroids, Dapsone and steroid injections.
\end{abstract}

Key words: Pemphigoid; topical steroids; dapsone; steroid injections; immunofluorescence

\section{Resumo}

Objetivo: O penfigóide membranoso mucoso (PMM) é uma desordem autoimume subeptelial bolhosa que geralmente afeta indivíduos mais velhos. Este relato de caso descreve a abordagem farmacológica do PMM em uma paciente jovem.

Descrição do caso: Uma paciente do sexo feminino, com 23 anos de idade, apresentava a gengiva eritematosa e ulcerada na região palatina e na região retromolar. A biópsia excisional total foi realizada e as análises histológica e de imuno-histoquímica confirmaram o diagnóstico clínico de PMM como causa da gengivite descamativa nesta paciente. A paciente foi tratada com esteróides tópicos, Dapsona $100 \mathrm{mg}$ diariamente e injeções de esteróides mensais $(40 \mathrm{mg})$. A resolução das lesões se iniciou após 12 semanas de terapia medicamentosa.

Conclusão: Este caso de PMM em uma paciente jovem foi efetivamente tratado com uma terapia combinada de esteróides tópicos, Dapsona e injeções de esteróides.

Palavras-chave: Penfigóide membranoso mucoso; esteróides tópicos; dapsona; injeções de esteróide; imunofluorescência

\author{
Gurumoorthy Kaarthikeyan a \\ N.D. Jayakumar ${ }^{a}$ \\ Ogoti Padmalatha a \\ Joseph M. Thachila \\ Sheeja Varghese a \\ Thiruvengadam Chandrasekar ${ }^{b}$
}

- Department of Periodontics, Saveetha Dental College and Hospitals, Chennai-77, India

${ }^{b}$ Department of Oral Pathology, Saveetha Dental College and Hospitals, Chennai-77, India

\author{
Correspondence: \\ G. Kaarthikeyan \\ Department of Periodontics \\ Saveetha Dental College \& Hospitals \\ 162, P.H Road, Velappanchavadi \\ Chennai - India \\ 600077 \\ Email:drkarthik79@yahoo.co.in
}




\section{Introduction}

Mucous membrane pemphigoid (MMP) is a humoral autoimmune disorder that usually affects older individuals, with the mean age of onset around 50 years old (1). The occurrence of MMP in young subjects is a rare event. MMP is characterized by subepithelial separation and the deposition of immunoglobulins - IgG and complements-C $3 \mathrm{c}$ along the basement membrane zone (2-4).

This paper presents a case report of MMP occurring in a young female patient, and its effective clinical management with the use of topical and systemic medications.

\section{Description of the case}

A 23 year-old female patient was reported to the Department of Periodontics of the Saveetha Dental College and Hospitals at Chennai, India, with the chief complaint of erosive gums and burning sensation of oral mucosa for the previous two years. The intraoral examination revealed erosive ulcerative lesions that were limited to the attached gingiva of the maxillary palatal region and the retromandibular region with a classic desquamative pattern seen in MMP.

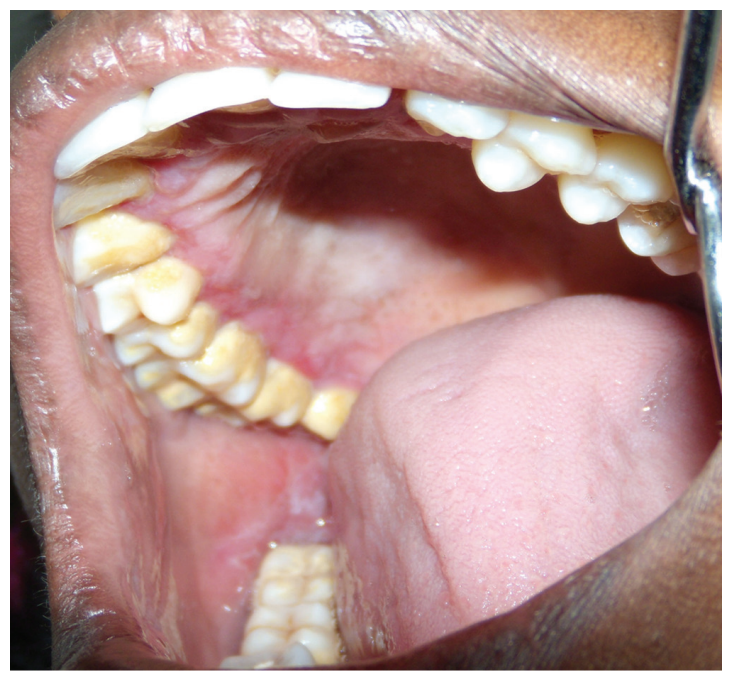

Fig. 1. Initial photograph showing the desquamative lesion in the maxillary palatal gingiva and retromolar mucosa.

A gingival biopsy was performed from the attached gingiva of the region of teeth 26 and 27. The histological analysis showed that the epithelium was lifted off with the subepithelial cleft, and there were dense infiltrates of lymphocytes admixed with few neutrophils and eosinophils. Afterwards a perilesional gingival sample from the maxillary palatal region was excised and submitted for immunohistochemical analysis.

Immunofluorescence stains showed linear interrupted bandlike fluorescence in $\mathrm{IgG}$ and $\mathrm{C} 3 \mathrm{c}$ in the dermoepidermal junction. The fluorescence was negative for $\operatorname{IgM}, \operatorname{IgA}$, $\mathrm{C} 1 \mathrm{q}$ and fibrinogen. Based on the clinical, histological and immunopathological findings, a final diagnosis of mucous membrane pemphigoid was established.
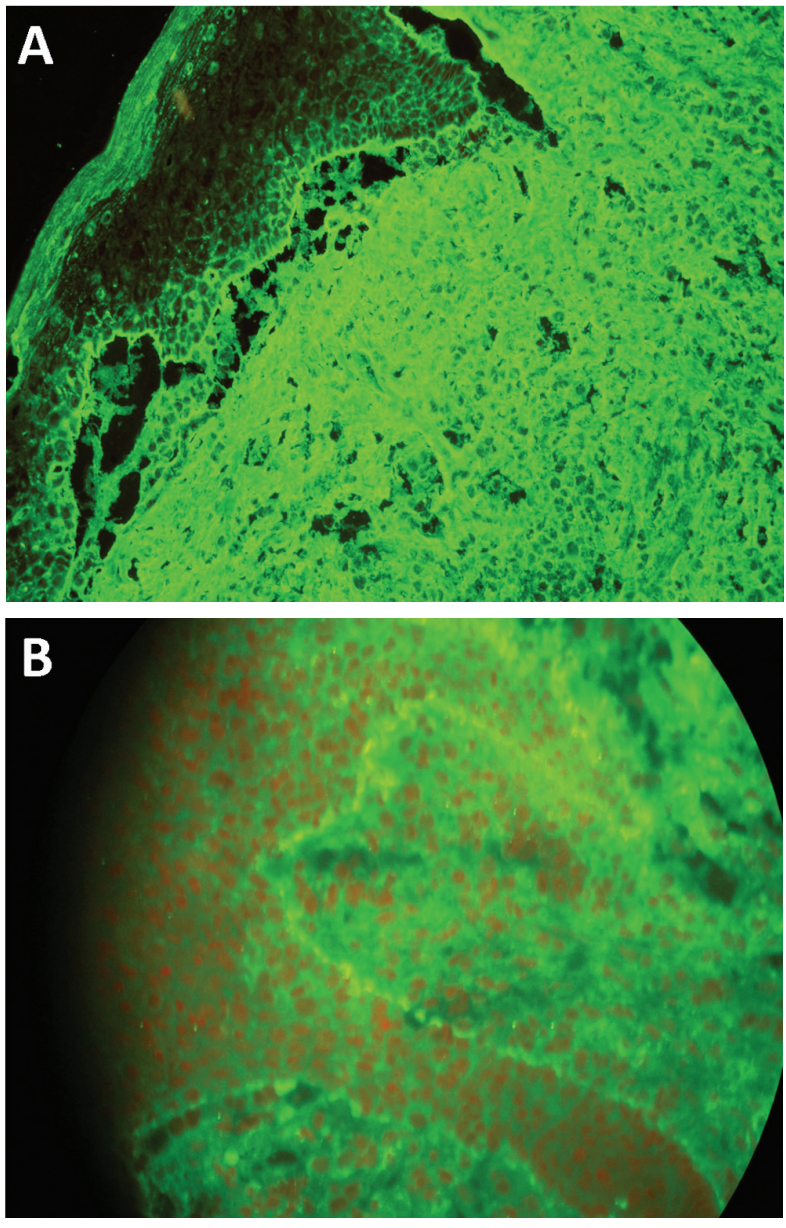

Fig. 2. Immunofluorescence images showing the positive band for $\lg G$ and $C 3 c$ (A and $B$, respectively).

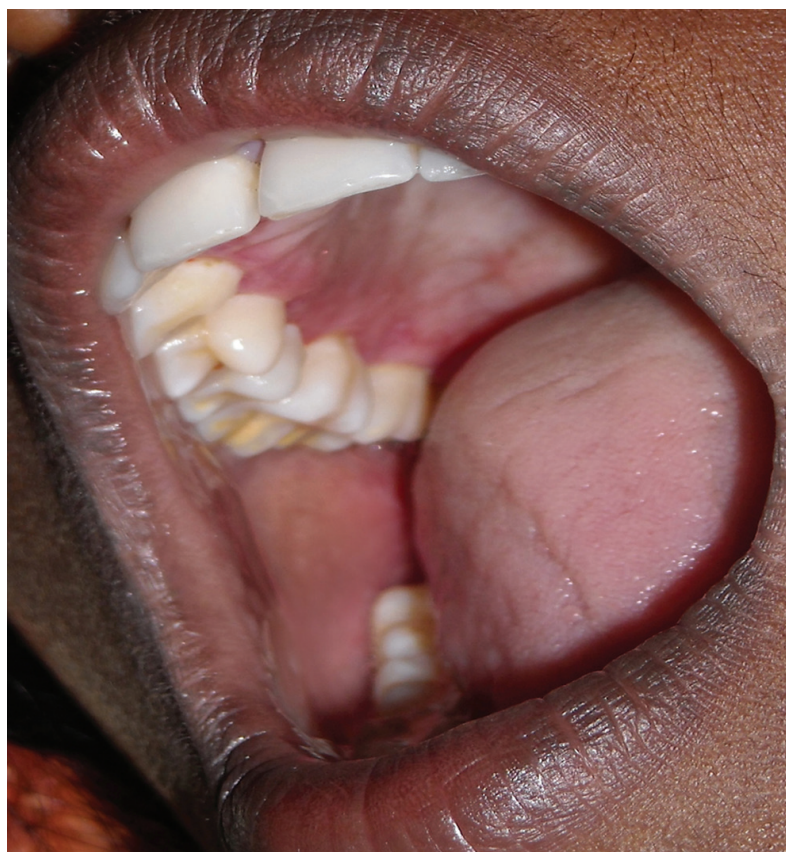

Fig. 3. Post-treatment photograph showing the healed lesions and normal aspect of the gingival and oral mucosa. 
Patient was initially treated with topical steroids and tetracycline (TCN) $500 \mathrm{mg}$ q.i.d plus nicotinamide. As the patient was intolerant to the high dosage of tetracycline, the treatment regimen was altered to use topical steroids and Dapsone $100 \mathrm{mg}$ daily plus steroid injection (triamcinolone acetate $40 \mathrm{mg}$ ) fortnightly. The overall condition improved but the lesions still persisted. Hence the steroid injections were given weekly along with Dapsone $100 \mathrm{mg}$ daily and topical steroids. The lesions started resolving after 12 weeks of therapy.

\section{Discussion}

This is a rare case report as far as periodontal literature is concerned - a case of desquamative gingivitis associated with mucous membrane pemphigoid occurring in a young female patient and its management with weekly steroid injections (40 mg). The case was diagnosed by clinical, histological examination and confirmed by direct immunofluorescence test (5). During the past 50 years, the mainstay of treat- ment for MMP has been systemic glucocorticoids $(1,2,6)$. However, the high doses needed to obtain clinical response are generally poorly tolerated, especially in young patients, and are associated with many adverse effects. In a German multicenter study of 369 patients with bullous pemphigoid, there was a considerable case fatality rate, and oral glucocorticoid treatment was identified as a major risk factor for many complications (7).

In another controlled study, patients with extensive BP treated with a potent topical glucocorticoid showed significantly better survival rates and disease control and less severe complications compared with those treated with oral prednisone (8). To avoid the adverse effects associated with the daily intake of oral steroids, we managed this MMP case effectively with topical steroids plus Dapsone $100 \mathrm{mg}$ daily and weekly steroid injections (40 mg).

Thus, our report concludes that this case of MMP in a young female patient was effectively managed with a combination therapy of topical steroids, Dapsone $100 \mathrm{mg}$ daily plus weekly steroid injection.

\section{References}

1. Borradori L, Bernard P. Vesiculobullous diseases: pemphoid group. In: Bolognia JL, Jorizzo JL, Rapini RP, editors. Dermatology. Philadelphia: Mosby/Elsevier; 2004. p. 463-70.

2. Chan LS, Ahmed AR, Anhalt GJ, Bernaver W, Cooper KD, Elder $\mathrm{MJ}$ et al. The first international consensus on mucous membrane pemphigoid: definition, diagnostic criteria, pathogenic factors, medical treatment, and prognostic indicators. Arch Dermatol 2002;138:370-9.

3. Person JR, Rogers RS III. Bullous and cicatricial pemphigoid. Clinical, histopathologic, and immunopathologic correlations. Mayo Clin Proc 1977;52:54-66.

4. Chan LS. Mucous membrane pemphigoid. Clin Dermatol 2001; 19:703-11.
5. Yih WY, Maier T, Kratochvil F J, Zieper MB. Analysis of desquamative gingivitis using direct immunofluorescence in conjunction with histology . J Periodontol 1998;69:678-85.

6. Carbone M, Carrozzo M, Castellano S, Conrotto D, Broccoletti R, Gandolfo S. Systemic corticosteroid therapy of oral vesiculoerosive diseases (OVED). An open trial. Minerva Stomatol 1998;47:479-87.

7. Rzany B, Partscht $K$, Jung $M$; et al. Risk factors for lethal outcome in patients with bullous phemphigoid: low serum albumin level, high dosage of glucocorticosteroids, and old age. Arch Dermatol 2002;138:903-8.

8. Joly P, Roujeau JC, Benichou J, Picard C, Dreno B, Delaporte E, et al. A comparison of oral and topical corticosteroids in patients with bullous pemphigoid. N Engl J Med 2002;346:321-7. 